doi: 10.15503.jecs2021.2.15.30

Journal of Education Culture and Society No. 2_2021

\title{
VERSIONS OF PRAGMATIC LIBERALISM: FROM RORTY TO DEWEY
}

\author{
ZLATYSLAV DUBNIAK \\ Department of Theoretical and Practical Philosophy, Faculty of Philosophy, \\ Taras Shevchenko National University of Kyiv \\ Volodymyrska 64/13, 01601 Kyiv, Ukraine \\ E-mail address: dubniakzo@gmail.com \\ ORCID: https://orcid.org/0000-0002-7487-1816
}

\begin{abstract}
Aim. The aim of this study is to analyse and evaluate two versions of the theory of liberalism which emerged within the philosophical tradition of pragmatism: Richard Rorty's "ironic liberalism" and John Dewey's "renascent liberalism."

Methods. The study is based on: 1) comparative analysis, which shows the differences and points of contact between Dewey's classical pragmatism and Rorty's neo-pragmatism, in particular between different versions of their liberal theories; 2) critical analysis, which made it possible to identify the shortcomings and advantages in the arguments of the above-mentioned philosophers.

Results. The author analysed Rorty's and Dewey's theories of liberalism in relation to their theories of reality, human specificity, and ethics. In this way, the specific liberal views of these American philosophers on such issues as the relationship between private and public, the main goals of politics, and the values of the social order were explicated. It allowed offering a thorough critique of Rorty's "ironic liberalism," and supporting of Dewey's "renascent liberalism."

Conclusion. While Dewey saw the mission of liberalism in enabling individuals to improve their experience, Rorty insisted on the need for a liberal policy of providing the basic conditions for individual self-creation. The main disadvantage of Rorty's neo-pragmatism, and, in particular, "ironic liberalism," was the exclusion from the philosophy of the modifying tools of human behaviour, which were expressed by the concepts of "good" or "virtue," in Dewey's "renascent liberalism." This circumstance necessitates a return from Rorty back to Dewey in the discussions on pragmatic liberalism.

Key words: philosophy of pragmatism, Richard Rorty, John Dewey, historicism, naturalism, liberalism
\end{abstract}

\section{INTRODUCTION}

Tn the history of philosophical thought, pragmatism is primarily seen as a movement that emerged at the turn of the $19^{\text {th }}$ and $20^{\text {th }}$ centuries as a reaction against foundationalism and absolutism. Pragmatists attempted to intro- 
duce alternative approaches to philosophical thinking. William James and John Dewey, being skeptical of classical philosophy, were not satisfied with the traditional approach. In the latter, ontological and epistemological theories developed into ethics and social philosophy and then, they were applied practically. Pragmatists, on the other hand, believed it is human individuality that must be at the core of philosophical thinking. They saw practicality to be more important than ontology and epistemology as well as ethical and social philosophy. According to pragmatists, philosophical theories must be built upon the idea of usefulness for human individuality. In other words, the theories of reality, truth, ethics and social order must first and foremost facilitate our well-being. These thinkers, inspired by Protestantism and the emerging science of psychology, saw the practical effect as the chief criterion for such well-being. More specifically, they believed that the good for human individuality lies in actions which integrate every part of our life and all of our experience in the most satisfactory way. In Pragmatism (1907), James described it as follows: "what works best in the way of leading us, what fits every part of life best and combines with the collectivity of experience's demands" (James, 1987, p. 522).

The progenitors of pragmatism believed that the practical good cannot be derived from theory alone. Therefore, one could say that pragmatism put its trust in human life as it is. However, this philosophy did not reject the theory completely. For instance, James and Dewey were supportive of the holistic-naturalistic theory of reality. They did not see it as an expression of the final truth though. For them, holistic naturalism was simply seen as the most satisfactory theory of reality in the era when they lived. James and Dewey believed that it offered the most value for human individuality. Likewise, their philosophical successor, Richard Rorty, adhered to a viewpoint which could be called "the historicist theory of reality." As a philosopher of the second half of the $20^{\text {th }}$ century, he was a prominent figure in the linguistic turn and a supporter of postmodernism. At that time, he saw a certain form of historicism to be of value for human individuality.

Among the most interesting issues within the contemporary tradition of pragmatism is the problem of the most satisfactory theory of social order. If human individuality is at the core of philosophical thinking, what kind of society and political system it would serve best? The major social philosophers of pragmatism, like Dewey and Rorty, would answer "liberal." However, the liberalism found in Rorty's writings at the end of the $20^{\text {th }}$ century is significantly different from Dewey's liberalism, which was being developed half a century earlier. In the present study, the author aims to explore not only the relationship between Rorty's theories of reality, human specificity and ethics, but also his theory of liberalism. This exploration will reveal why Rorty's liberal theory, being linked to contingentist historicism, does not stand up to scrutiny, while Dewey's liberal theory, which is linked to holistic naturalism, is more satisfactory within the pragmatic philosophy.

A substantial exploration of this theme may be found in Christopher J. Voparil (2014). In his study, the author argued for the continuity of ideas 
expressed by these two major figures in the philosophy of pragmatism. He also tried to demonstrate how Rorty managed to build upon Dewey's constructive ideas. Similar studies were undertaken by Colin Koopman, David Rondel and others (Koopman, 2006; Rondel, 2011; Voparil, 2014). However, this approach may be seen as essentially neglecting the distinctions between Dewey's and Rorty's views. It also takes no notice of Rorty's ideas that do not hold up against criticism. Meanwhile, Richard Shusterman's earlier article is an example of a more analytical and coherent exploration (Shusterman, 1994). In the article, the author compared the nuances of each of the two thinkers' positions as well as exposed the shortcomings of Rorty's viewpoint. The following study expands on the approach that was brilliantly presented by Shusterman as well as other researchers, namely, James Marshall and Patric Deneen (Deneen, 1999; Marshall, 1995; Shusterman, 1994).

\section{RORTY'S CONTIGENTIST HISTORICISM AND ITS PROBLEMS}

Richard Rorty's neo-pragmatism is one of the movements within the pragmatism tradition. It emerged and was developed by the American philosopher between 1970s and 2000s. Rorty preserved the theoretical basis shared by the classical pragmatists, i.e. the adoption of anti-foundationalism and further elaboration of the philosophy that serves human individuality. Being James's and Dewey's successor, Rorty proceeded from a premise that the fundamental structures of reality cannot be cognized. This philosophy gave up on Platonic or Kantian attempts to find a reliable framework for all being.

Pragmatists' anti-foundationalism led to creating a new basis for philosophical thinking, and it was chosen to be human individuality. In his work Rorty referred to the classics of pragmatism as to the "anti-philosophical thinkers." In his view, they rejected Platonic questions on the nature of Truth and Good and saw universal theories of the nature of reality, the essence of knowledge or the nature of a human being as unjustified. In the $19^{\text {th }}$ century, two philosophical movements crystallised, namely, "transcendental philosophy" and "empirical philosophy" (Rorty, 1982a). According to the former, the Truth is beyond space and time, while the latter saw it within space and time. However, both movements distinguished between a realm of idle contemplation and a realm of true knowledge. According to Rorty, "pragmatism cuts across this transcendental/empirical distinction by questioning the common presupposition that there is an invidious distinction to be drawn between kinds of truths" (Rorty, 1982b, p. xvi). James and Dewey, as Rorty interpreted them, believed that there is nothing deep within a human being, except for what one has put there himself or herself. There is neither a life-long criterion formed in the process of one's practical activity nor an eternal standard of rationality or evidential reasoning. Such realms of human activity as science, art, ethics or literature are simply means of capturing various facets of the universe, none of which having a transcendental status or revealing a unique type of truth. All 
of them are just meant to help us answer the question "about what will help us get what we want (or about what we should want)" (Rorty, 1982b, p. xliii). Thus, the achievement of actual and possible human goals needs to replace the attempts to uncover the eternal truth.

In much of his writings, Rorty appeared to follow the ideas of classical pragmatists. It is particularly evident in some of his interpretations of Dewey, the major figure for the thinker. In his article, Rorty writes that Dewey refused to see philosophy as an autonomous activity seeking rational justification (Rorty, 1994). He was neither a foundationalist like Kant nor an avant-gardist who argues that a radical shift in language is necessary to pursue justification. For Dewey, philosophy was rather a "reconciliatory activity," a realm of ideas that need to be utilised, namely, to reconcile the old and the new within culture (Rorty, 1995, p. 203). In this paper, Rorty presented Dewey's pragmatic philosophy as anti-foundationalistic, not claiming to be all-encompassing and universal, being supportive of a certain contingent culture. In his article, a contemporary scholar of pragmatism David L. Hildebrand remarks that Rorty referred to Dewey as his "principal philosophical hero" (Hildebrand, 2020). Rorty attributed his inspirer's success to his critical mind, rebellion against the traditional philosophical quest for an innate structure of reality, certainty of knowledge and timeless moral norms as well as to his focus on the political sphere, in particular on his project of building a social democracy (Hildebrand, 2020, pp. 338-339).

In his interview "After philosophy, democracy" (1994), Rorty remarked that he sees no fundamental distinction between Dewey's pragmatism and his own viewpoint. The only difference is his special attention to the philosophy of language, which Rorty's predecessor lacked (Rorty, 1994). However, it may be assumed that Rorty himself was aware of a deeper divergence between the classical pragmatism and his own neo-pragmatism, which becomes clear from his works on Dewey's philosophy: "Dewey's metaphysics" (1977) and "Dewey between Hegel and Darwin" (1994). In the first article, Rorty agreed with George Santayana's view of Dewey's "empirical metaphysics" as a contradiction in terms. On the one hand, in his work "Experience and Nature" (1925), Dewey criticised the old metaphysics from the historical and sociological perspective. On the other hand, in this very work he was developing a new metaphysics claiming to reveal "the basic types of involvement" - that is, to be a comprehensive theory of experience (Rorty, 1982a, p. 77). Therefore, while Rorty valued Dewey's view on the traditional philosophical metaphysics as detrimental to Western culture, he made the mistake of turning this criticism into a new description of "nature" and "experience" (Rorty, 1982a, p. 85).

In the second article, Rorty repeatedly attempted to present how Dewey was supposed to reason as opposed to how he actually did. His philosophy would not be rooted in radical empiricism, panpsychism and holism, but rather in a firmer historicism (Rorty, 1998b, pp. 293-294). According to Rorty, Dewey tried to show the continuity between all the species, believing they differ only in the way their experience is organised. Instead, "Dewey should have dropped the 
term 'experience', not redefined it. He should look elsewhere for continuity between us and brutes. He should have... said that the only relevant break in continuity was between non-language users (amoebas, squirrels, babies) and language users" (Rorty, 1998b, p. 297).

Rorty believed that neither philosophy nor any other discipline can truly reveal reality or human nature. Therefore, Rorty saw Dewey's holistic naturalism as a remnant of foundationalism. Rorty himself contemplated the world and a person through the lens of historicism, which he viewed as a reasonable theory within the anti-foundationalistic paradigm. At this point, the discussion may be about three integral parts of Rorty's neo-pragmatism: first, the ontology of contingentist historicism; second, the anthropological pair of language and imagination; and third, the ethics of self-enlargement. A detailed look will be taken at each of them in this article.

Rorty tried to assert his own anti-foundationalitic theory of reality which can be called contingentist historicism. Undoubtedly, Rorty partly retained Dewey's naturalistic viewpoint since he actively applied the notion of "habits" as well as wrote about the suffering caused by a failure to meet some basic life conditions, e.g. because of poverty, illness or violence. However, Rorty found it important to highlight the contingency of these or any other conditions. Things and people are neither defined by a hidden historical teleology, nor by their innate nature. The world is contingent. As Rorty writes, "our language and our culture are as much a contingency, as much a result of thousands of small mutations finding niches (and millions of others finding no niches), as are the orchids and the anthropoids" (Rorty, 1989, p. 16).

Apart from the concept of "contingency," the development of neo-pragmatism involved other historicist notions like "language" and "imagination." They were all conceived as abilities that allow a person to lead a specific human way of life in a contingent historical reality. The conditions and ways of life of people are closely connected with an accident; therefore, a reference to non-logocentric capacities can serve as the best description of a human nature. For Rorty, "language" and "imagination" were best suited for this.

Rorty made the concept of "language" one of the central ones in his theory of human specificity, as well as all the concepts derived from it, such as "description," "vocabulary" or "language game." In the spirit of the classics of pragmatism, (Rorty, 1989), argued that the world exists independently for a human being. But the truth about this world does not exist in such a way. People should not "run together the fact that the world contains the causes of our being justified in holding a belief with the claim that some nonlinguistic state of the world is itself an example of truth, or that some such state 'makes a belief true' by 'corresponding' to it" (Rorty, 1989, p. 5). According to Rorty, a human chooses a language game and this choice is not the result of reflecting exemplary truth. Simultaneously, the choice of language game is not a random act. It is subject to the mechanism of habit.

Initially, it may seem that the dependence of language game on the mechanism of habit in Rorty is an adherence to the naturalistic position of Dewey and 
other classics of pragmatism. However, clarity is introduced by another linguo-centric concept, i.e. "metaphor." The American philosopher believed that language has no purpose in the form of expressing meanings or representing facts, as it is a set of metaphors. Most expressions of our language are "dead metaphors." Thus, these are statements that previously expressed new ways of acting and thinking but have now become familiar and banal. Instead, the metaphors which have not become "dead" help people change their actions and thoughts (Rorty, 1989, pp. 18-19). Therefore, according to Rorty, language does not serve to reflect reality, but primarily to change something. The direction of this change could be called a "leap into the unknown." Living metaphors can be a tool to influence the world in order to achieve certain human goals in a more efficient way. They can also serve to change these particular goals. Hence, for Rorty, along with linguo-centric concepts, there was the concept of "imagination" as the human ability to seek alternatives to existing beliefs and goals. Imagination is free from the pressure of existing conditions or individual dispositions. It is the main engine of "redescription" and "faculty for creating metaphors" (Rorty, 1989, p. 36). For Rorty, imagination was especially important in terms of the ability to put oneself in the place of people unlike us, to have "sensitivity," "respect" and "trust" to them.

Thus, the subordination of the language game to the mechanism of habit meant not the rigid demands of the naturalistic forces among which a human being lives, but rather some inertia of metaphors towards their habitualisation, which people are forced to accept. As it has already been mentioned, Rorty did not consider a person completely detached from natural conditions. However, the historicist terminology of the American philosopher made this world of conditions different from what Dewey imagined. The contemporary philosopher of pragmatism, Richard Shusterman, argued that Rorty identified contingency with complete coincidence. For him, there was either complete necessity or complete chance. Dewey, on the other hand, was aware of the existence of norms of biology and society as certain regularities (Shusterman, 1994, p. 398).

As a contingentist historian, Rorty viewed a human being primarily as a linguistically and imaginatively constructed individuality. This point of view differed significantly from Dewey's holistic-naturalistic position, according to which the main human abilities were "experience" and "intelligence." For Dewey, experience existed in the fusion with intelligence. Dewey argued that human experience was not an accumulation of isolated, static, and limited material, as ancient philosophers and early modern empiricists believed. It changes according to the challenges of life and should be understood as "adaptive courses of action, habits, active functions, connections of doing and undergoing; sensorymotor co-ordinations" (Dewey, 1920, p. 91). Dewey considered experimental intelligence to be the organising factor within the experience. He defined it as the human ability to put forward hypotheses for practical testing, correction, and dissemination to the extent that they fail or successfully give our current life the guidance it needs. Intelligence is not something a person possesses once and for all. It is constantly being formed, and its preservation 
requires constant attentiveness in monitoring the consequences, a receptive will to learn and courage in reorganisation (Dewey, 1920, pp. 96-97).

The contingent-historical feature can also be seen in Rorty's view of human morality. In An Ethics for Today (2010), the American philosopher argued that people could not choose moral ideals on a neutral basis. In the past, the concept of "redemption" provided a distinction between the lower, animal, mortal part of the soul, and the higher, divine, immortal one. The redemption was the triumph of the second over the first. However, in the $20^{\text {th }}$ century, many intellectuals stopped associating spirituality with redemption and began to believe that spirituality did not require "the hope to transcend finitude" (Rorty, 2010, p. 13). In another article Rorty wrote that the $20^{\text {th }}$ century lost interest in the Platonic-Nietzschean question "What is our nature?" and instead began to ask "What can we make of ourselves?". Accordingly, we began to think of ourselves "as flexible, protean and self-shaping animal than as rational animal" and began to see the moral goal not in immortality, eternity and deity, but in the gradual making "things better for ourselves" (Rorty, 1998c, p. 175).

In "Rationality and Cultural Difference" (1998d), Rorty noted that Dewey abandoned rationality in the sense of the moral ability to set goals other than survival in order to create value hierarchies. According to Rorty, Dewey was a supporter of rationality in two other senses: 1) as a "technical reason," "skill at survival" which is "ethically neutral" and 2) as "tolerance," "willingness to alter one's own habit," "reliance on persuasion rather than force" and "freedom" (Rorty, 1998d, p. 186). In Rorty's interpretation, Dewey's notions of human morality asserted such a variety of ways of life that, due to the lack of rational access to eternal models of morality, it could not be brought under any clear standards. Therefore, morality is following different individual ways of living; it is a creative change from one way to another; and also, it is a refusal to interfere in the individual ways of other people, a tolerant attitude towards them. Based on this view on Dewey's ethics, Rorty noted in Ethics Without Principles (1999a) that "it is best to think of moral progress as a matter of increasing sensitivity, increasing responsiveness to the needs of a larger and larger variety of people and things" (Rorty, 1999a, p. 81).

Such a reading of Dewey's work deviated quite far from the ideas expressed there. For Rorty, as for his predecessor, human morality was about improving. However, by improvement Rorty meant something different than Dewey. As an anti-foundationalist who embraced contingentist historicism, he associated human morality not with Platonic or Kantian "reason" and not with Dewey's "experimental intelligence" but with "language" and "imagination." He considered self-enlargement and self-creation to be the major moral goal. Therefore, in relation to oneself, Rorty's moral figure had to seek an imaginary expansion and transformation of one's goals, while in relation to others, there was an imaginary sense of loyalty, which should ideally be loyalty to all people, or even to all living beings (Rorty, 2007, p. 45).

The key difference between Dewey's and Rorty's moral theories was their different attitudes toward the phenomenon of moral standard. There is no doubt 
that both philosophers denied the possibility of knowing the ahistorical moral standards of which Platon or Kant spoke. However, Dewey did not abandon historical and transitional moral standards. Unlike Rorty, in his work Ethics (1908), he made them an integral part of his moral theory. For Dewey's ethics of improvement, concepts such as "virtue" or "good" expressed the basic components of moral behaviour, "tendencies relatively set, ingrained, and embodied in fixed habits" (Dewey \& Tufts, 1908, p. 362). Without them, one cannot hope for improvement or even a stable life. Improvement is impossible, since a person without standards can only dissipate into random lifestyles. Stability is also impossible, as the individual cannot adapt to their environments in the absence of temporary patterns of successful behaviour. Therefore, although in Reconstruction in Philosophy Dewey tried to de-absolutize moral principles and rules, he also argued that they were important "intellectual instruments for analyzing individual or unique situations" and for useful actions on this basis (Dewey, 1920, p. 162-163). As rightly noted by James M. Albrecht, who commented on Dewey's ideas, "enduring and inclusive ends" are essential for human happiness (Albrecht, 2012, pp. 220). Rorty did not have such an attitude to moral standards. For him, any attempts to talk about such fixed samples were questionable. Absolute moral relativism as a position of recognising in a given situation any rules as useful as any other was absurd for Rorty. But he was a supporter of radical moral pluralism. Rorty's attempt to speak of moral standards was seen as a threat to the return of the foundationalistic discourse of historical moral standards.

In author's opinion, Rorty could not offer an acceptable moral theory based on his historicist theories of reality and a human being. This theories argued that the connection between a human being and the world was too weak. Therefore, the classic pragmatist notions of "problem solving" or "improvement" used by Rorty could not speak of anything more than an empty voluntaristic change of certain dispositions or states of affairs by imaginary vocabulary change. Whereas for Dewey "improvement" meant the realisation of the potential of individuality, for Rorty, who was greatly inspired by the struggle against foundationalism, the same concept meant a re-establishment of individual dispositions to avoid the repressive influence of habitual and, therefore, depressing ways of life.

\section{PRAGMATIC LIBERALISM: CRITICISM OF RORTY AND THE REACTUALISATION OF DEWEY}

All of Rorty's neo-pragmatic theories went hand in hand with his understanding of socio-political issues. He was also a liberal thinker. Like Dewey, Rorty considered the service to human individuality to be of the highest political value. However, as shown above, he did not understand individuality the same way as his predecessor. Accordingly, in Rorty's neo-pragmatism, the liberal service of individuality also had its specificity. One can clearly see 
this originality through the analysis of Rorty's vision of the private and public spheres. First, however, it is essential to provide a brief overview of Dewey's standpoint.

Dewey divided the effects of human activity into two types: those that affect directly interacting individuals and those that affect people outside of such interactions. The first means "private," while the second - "public." When the side effects of human actions called "public" are perceived and realised, they begin to be regulated. An example of this was the emergence of a democratic state and the public (community), which aimed to protect the common interests of all its members, as well as the interests of those who may naturally occupy an unequal position (people with disabilities, the elderly, women, etc.). Dewey understood the threats posed by this new era. It was clear to him that in modern times, when the side effects of human interactions have become manifold, profound, and complex, the achievement of goals by the democratic state and the public has become problematic (Dewey, 1946, p. 126).

That was the reason why in Liberalism and Social Action (1935), Dewey saw the mission of "renascent liberalism" and new "social liberalism" in the intellectual regulating the situation in a society for the sake of the full realisation of individuals' potential. He emphasised "the role of freed intelligence as a method of directing social action" in the direction of increasing "liberty and the opportunity of individuals to secure full realisation of their potentials" (Dewey, 1963, pp. 50-51). This was to include the cultivation of experimentation, personal virtues, and organised social action. This is what Dewey called "creative democracy" or "democracy as a way of life" (Dewey, 1998, p. 342). It should be emphasised that for Dewey, the private and the regulated public (political) were closely linked. Efficiency, usefulness in the philosophical and pragmatic sense of the word united them, the difference was only in the scale of action.

Rorty had a different view of the content and relationship of the private and the public. His texts, more than Dewey's, were aimed at separating and protecting the private sphere. In Contingency, Irony, and Solidarity, Rorty "tries to show how things look if we drop the demand for a theory that unifies the public and private, and are content to treat the demands of self-creation and of human solidarity as equally valid, yet forever incommensurable" (Rorty, 1989 , p. xv). He argued that the most we can do to bring the private and public spheres closer together is to define the goal of a liberal society as providing individuals with the freedom to be as private and fancy as they want, of course, without harming others (Rorty, 1989, p. xiv). For such reasons and purposes, Rorty partly took the position of the early liberals and believed that the state or organised public activities should not interfere with the private lives of individuals, except when the way of living such a life threatens the freedom of others.

At the same time, in the spirit of Dewey's "social liberalism" Rorty no longer believed that organised social action should be minimised and reduced to providing the minimum conditions for the realisation of the freedom of each 
individual, as the early liberals argued. Instead, the state and the public must exercise control and redistribution to ensure that the main goal is achieved, i.e. to protect the common interests of all its members. In "Failed prophecies, glorious hopes" (1998), Rorty called the hope for human justice a basis for meaningful human life. He wrote that today one should not hope to achieve the fraternity that the Gospel calls for without the hope that public policy will redistribute resources and opportunities in a way that the market will never do (Rorty, 1999b, p. 205).

The similarity between Rorty's liberalism and Dewey's "social liberalism" is even greater when one looks at some of the first statements in "A defense of minimalist liberalism" (1998). Rorty wrote that "you get more reflective people, people better suited for the responsibilities of self-government, whenever you provide more education, security, and leisure" (Rorty, 1998a, p. 119). He also noted that "Americans were more trusting, tolerant, and self-confident during the King years than they are now; ... this seems explicable by the fact that during those years the gap between rich and poor was narrowing, whereas more recently it has been widening. In the last twenty-five years, most Americans have lost the sense of economic security which the previous twenty produced. The change in national mood seems to me sufficiently accounted for by economic facts" (Rorty, 1998a, p. 124). There is no doubt that Dewey also placed the self-government and trust of citizens in close dependence on the social conditions that shape them. Dewey was troubled by similar problems of the first half of the 20th century and he saw the need for liberalism, which encourages organised social action to create better and fairer social conditions.

For Rorty, public regulation was very important. In Achieving Our Country: Leftist Thought in Twentieth-Century America, Rorty considered himself a left-wing thinker and regarded Dewey to be of the same kind. For Rorty, his predecessor was a left-wing reformer who drew his political ideas from the American progressive movement. Dewey, according to Rorty, was a supporter of a "classless and casteless society," which produced "less unnecessary suffering" and "greater diversity of individuals - larger, fuller, more imaginative and daring individuals" (Rorty, 1999c, p. 30). Dewey saw a progressive path to such a society in the gradual, reformist solution of many problems. He was a supporter of the civic religion of social experimentation. With thinkers and activists such as Dewey, Rorty linked the positive changes in American society toward social justice that took place in the first sixty years of the $20^{\text {th }}$ century.

Much attention to the topic of public regulation can be found in other Rorty's works. In "Failed prophecies, glorious hopes”, Rorty wrote that we could no longer accept the New Testament and the Communist Manifesto as prophecies to come true. However, these texts can still inspire us and give hope that "someday we shall be willing and able to treat the needs of all human beings with the same kind of respect and consideration with which we treat the needs of those closest to us, those whom we love" (Rorty, 1999b, pp. 202-203). He noted that today the Communist Manifesto is a better book for young people than the New Testament, because the latter is an imperfect emphasis on the 
afterlife and it can push to turn a blind eye to the shortcomings of the mortal life. The New Testament is a work of a time when people did not believe in the possibility of a fundamental change in social conditions. Whereas modern people are the utopists of earthly life. However, Marx's work today is also a bad utopia, because it contains the erroneous idea of total transformation. Thus, as Rorty believed, nowadays, it would be good to get a new text that would not have apocalyptic and revolutionary ideas, but the reformist ones instead. It had to spell out "the details of a this-worldly utopia without assuring us that this utopia will emerge full-blown, and quickly, as soon as some single decisive change has occurred - as soon as private property is abolished, or as soon as we have all taken Jesus into our hearts" (Rorty, 1999b, p. 208).

According to Rorty, an ideal liberal society should be based on consensus on the question of a social organisation in which everyone is given a chance at self-creation. And the main questions in it which are: "(1) how to balance the needs for peace, wealth, and freedom when conditions require that one of these goals be sacrificed to one of the others and (2) how to equalize opportunities for self-creation and then leave people alone to use, or neglect, their opportunities" (Rorty, 1989, p. 85). Rorty spoke little about a specific programme of social reform that should embody such left-wing liberalism. In an interview "The Next Left. Interview by Scott Stossel," he suggested that health care, as well as primary and secondary education should be made available, that state funding for election campaigns should be introduced, and that an international workers' organisation and a trade union confederation should be established to seek its reformist influence on politics (Rorty, 1998e).

However, as the title of Rorty's program article, "A Defense of Minimalist Liberalism," the American philosopher was taking a step back to the early liberals. Preserving the position of the early liberals was to prioritise the private sphere over the public. For Rorty, the "minimal liberal" is the best version of the liberal, as it frees politics from moral philosophy, does not need a theory of self at all, and, in particular, it does not need a theory that distinguishes between reflexive and non-reflexive people. It is important not to highlight the special abilities of a human being (reason, will, inclination, etc.), which allow people to go beyond the built-in goals and needs of the selfhood. According to Rorty, the main thing for a pragmatic, minimal liberal position is an interpersonal compromise that people can freely create on the basis of "justified trust" and "irony" as openness to the wider horizons of life (Rorty, 1998a, p. 122).

It may be stated that for Rorty, people are primarily private individuals who are engaged in meeting their needs and self-creation. He passionately defended the separateness of each individuality. For him, no external standards of behaviour could be authoritative models for the individuality. Any attempt to speak of "true" goods is foundationalistic and violent if attributed to citizens. Therefore, the state and the public should not make a moral interference in the private life of any individual. The moral obligation of the state and the public as specific associations of these individuals is to provide, through imagination and interpersonal sensitivity, the necessary social conditions for 
the elimination of violence and suffering and to open opportunities for individual satisfaction of needs and self-creation.

Rorty wrote that for a liberal society, permissiveness is central when it comes to words, not deeds, the power of persuasion, not coercion, and that "a liberal society is one that is content to call 'true' whatever the upshot of such encounters turns out to be" (Rorty, 1989, p. 52). This idea reflects Rorty's view of individuality as a linguistic being endowed with certain contingent vocabulary. There is no meta-vocabulary that would provide individuals with criteria for the truth or proper argumentation of statements. Each individual has one's own vocabulary, no one can impose any universally correct vocabulary on others. What can be hoped for is the expression of imagination, sensitivity and, consequently, the voluntary coordination of vocabularies for the political purpose of reducing suffering and creating opportunities for individual self-creation.

We may talk about the gap between private and public in Rorty's views. It corresponded to contingent historicism and an asserted understanding of the individual as a separate unit, which, although conditioned by social circumstances, is still unique. The general purpose of one's life is the realisation of his or her own needs and the realisation of self-creation. In the private sphere, the individual can be what he or she wants to be. Moreover, this is the main moral value. In the public sphere, an individual retains his or her unique identity, but at the same time must be concerned with the common good and social justice. The gap between the private and the public in Rorty's views may be discussed because the possibility of reconciling the exhausted voluntaristic aspect of individuality with its political aspect is problematic. In other words, one may ask whether an individual who is primarily concerned with one's own "aestheticisation" and "self-creation" will realise the importance of politics. Even if one realises it, will such person be capable and competent in political action? The author of this article assumes that these questions should have a negative answer.

It may be supposed that Rorty's contingentist historicism, which conceived of a human being primarily as a linguistic and imaginative being, is unsuitable for politics. The American philosopher "united" people into a common reality of suffering. However, he "separated" them from the atomized reality of unique individual vocabularies, metaphors and feelings. All people suffer and seek to reduce suffering, but because each individual only reproduces or creates one's own vocabulary, there is no sufficient basis for political understanding, much less to distinguish between useful and harmful in political activity.

Rorty insisted on the separation of private and public spheres. He seemed to believe that an individual could switch from one "mode" to another. The prototype of Rorty's private personality was an ironic person who believed that nothing had an inner nature or real meaning. The ironist considers vocabularies to be contingent poetic achievements, not the fruits of persistent inquiry in accordance with pre-formulated criteria. "Her method is redescription rather than inference," as Rorty wrote in Contingency, Irony, Solidarity (Rorty, 1989, 
p. 78). The prototype of public individuality was a liberal - a person who strives for social cooperation and considers the main "obligation to diminish cruelty, to make human beings equal in respect to their liability to suffering" (Rorty, 1989 , p. 88). The change from an ironic to a liberal approach was seen by Rorty as consistent. He used the synthesizing term "liberal ironist" or "ironic liberal." This is a person who distinguishes between private and public. This person can have any private goals and describe herself and others in vocabularies she wants. But as a liberal, she is aware of the existence of different vocabularies that are important to other people, as well as the various ways in which she can humiliate them (Rorty, 1989, pp. 91-92).

It may be presumed that such a switch between the aestheticizing private and the sensitive public is incompatible and dangerous in case it takes place. Undoubtedly, one can profess Rorty's ideal of private satisfaction of needs and self-creation, and at the same time participate in politics. However, the sensitivity shown by such a politically active person is likely to be harmful sentimentality. It is probable that we will be able to see an attempt to protect different racial, sexual, and many other groups that do not have the access to equal opportunities. However, such an attempt is likely to lead to unequal opportunities for unmarginalised groups. What is more, the sensitivity of the aestheticising of individual risks is becoming a new yoke for those to whom it is directed. The new institutional conditions developed by such a policy are likely to provide not the access to opportunities, but new conditions for safe stagnation. After all, in order to create opportunities for political development of an individual and satisfying one's basic needs, as well as to create equal access to these opportunities, certain patterns of good behaviour and human abilities are needed.

Rorty's anti-foundationalistic struggle against human patterns and progressive abilities has gone too far in denying any attempt to appeal to them. This can be seen in his reasoning in "Afterword: Pragmatism, Pluralism, and Postmodernism" (1998). Rorty abandoned the idea of morality as obedience to something superhuman in favor of the idea of morality as self-creation and horizontal progress. Together with some intellectuals of the $19^{\text {th }}$ century, he believed that the meaning of one person's life had little in common with the meaning of another's life, and that social cooperation should be separated from the classic question: What is the Good for Life for Man? He considered the point of view of the utilitarist John Stuart Mill, as well as the later classics of the philosophy of pragmatism, who thought that the goal of social organisation is "freedom rather than virtue." Virtues should be understood as "a collection of unrelated sorts of excellence." According to Rorty, these philosophers denied the idea of an additional ingredient, a certain essential human ability (such as reason, will, inclination, etc.). They defended "philosophical pluralism," according to which there is a "potential infinity of equally valuable ways to lead a human life" (Rorty, 1999d, pp. 267-268). The statements in The Priority of Democracy to Philosophy, in which Rorty wrote that liberals "put liberty ahead of perfection" and considered that "even if the typical character types of liberal 
democracy are bland, calculating, petty, and unheroic, the prevalence of such people may be a reasonable price to pay for political freedom" were similarly demonstrative (Rorty, 1991, p. 190).

In his anti-foundationalism, Rorty followed Dewey. The latter criticised the idea of reason as the ability to reflect reality and know the true Good. However, Dewey argued that a human being has such an ability as experimental intelligence, which formulates practical hypotheses and, after their active application, makes transitional verdicts on the ability of these hypothetical actions to successfully reconcile human experience, that is, to cause good results. Dewey also criticised the notion of fixed patterns of goods and their hierarchy. Nevertheless, he did not abandon either the notion of "good" or the notion of "virtue," but emphasised their importance as modifiers for moral behaviour. Dewey moved from foundationalism to holistic naturalism. In turn, Rorty came to contingentist historicism, in which there was no place for experimental intelligence, but instead there was language game and imagination; there were no virtue-modifiers, but there were only a variety of equivalent ways of living. These differences can be considered serious enough to call into question, for example, the opinion of such a proponent of the integration of Dewey's and Rorty's pragmatisms as Colin Koopman. According to him, the differences between such concepts of pragmatists as "experience" and "language" fade in comparison with the deeper agreement of these philosophers on the hope for a better future (Koopman, 2006, p. 112). In fact, these differences only show more clearly that "hope," "better," and "future" did not mean the same things to Dewey and Rorty.

The departure from the discourse of human virtues and controlling abilities in Rorty made it impossible to link private and public. The regulation of the public sphere requires private individuals not only to switch to its specific purpose at a certain point in order to serve the common good and social justice. First of all, the regulation of the public sphere requires that it should be united with the private sphere by the common qualities and skills of individuals. In order for private individuals to be able to regulate the public sphere, they need to have a wealth of experience in private life in the Dewey's sense of these terms. After all, the public consequences of actions differ from private ones only in scale. What unites them is their origin: they present a combination of certain elements of natural reality. Therefore, if an individual is experienced in combining these elements in the private sphere, then one has a good chance to be successful in regulating the public sphere. The same logic works in the opposite direction. When the public and the state achieve a high level of quality and the ability to care for the common good and social justice, individuals in the private sphere are also likely to be successful. Dewey understood this, so he did not create two contrasting regimes of human existence. In his philosophy, there was no rigid division into the aestheticising part of an individual, which is different from the other part, which values social justice. Dewey, on the other hand, believed that there was only one improvement in experience that extended from private to public action. 
Therefore, for Dewey, a human being remained a liberal in both the public and private spheres. In both areas, one works to develop individuality, i.e. to increase the effectiveness of experience. In the private sphere, one cares about one's own individuality, while in the public sphere, he also includes the care about the individuality of other people. There is no conflict between the two spheres, as the regulation of the public does not impose strict and rigid rules on individuals that would suppress their individual potential, but, on the contrary, it offers examples and opportunities for its disclosure. For its part, private life is not isolated or degraded to the use of public for private purposes. The distinction and combination of the private and the public in Dewey's works may be considered more careful and justified than in Rorty's writings.

\section{CONCLUSION}

It may be concluded that Rorty, using ideas of contingentist historicism, saw individuality primarily as a unique individual who satisfies one's own needs and creates oneself. Accordingly, the mission of liberalism is to serve such an individual through the political protection of one's individuality and the provision of basic conditions for one's existence and self-creation. Dewey saw individuality through the eyes of holistic naturalism as a developed social individual who benefits from the successful consequences of one's actions and improves along with others. The mission of liberalism, therefore, is to serve such an individual by creating effective conditions for existence.

Critically questionable point of Rorty's neopragmatism was the rejection of independent structures of natural reality at the level of ontology, experimental intelligence at the level of anthropology, and virtue-modifiers at the level of ethics. Rorty's ironic liberalism was just as erroneous, because it did not regard historicized entities as a basis and distorted the goal of politics to unconditionally voluntaristic defense of the individual uniqueness of each person.

If the $21^{\text {st }}$ century requires a rethinking of liberalism, then within the tradition of pragmatism academics should turn to Dewey's liberal theory. At the time of current intensification of radicalism and populism, its emphasis on improving experience, the importance of intelligence, virtue, and experimental political cooperation has increased its relevance.

\section{REFERENCES}

[1] Albrecht, J. M. (2012). Reconstructing individualism: A pragmatic tradition from Emerson to Ellison. New York: Fordham University Press.

[2] Deneen, P. J. (1999). The politics of hope: Rorty, Havel, and the democratic faith of John Dewey. Social Research, 66(2), 577-609.

[3] Dewey, J. (1920). Reconstruction in philosophy. New York: Henry Holt and Company.

[4] Dewey, J. (1946). The public and its problems: An essay in political inquiry. Chicago: Gateway books.

[5] Dewey, J. (1963). Liberalism and social action. New York: Capricorn Books. 
[6] Dewey, J. (1998). Creative democracy - the task before us. In: L. A. Hickman \& T. M. Alexander (Eds.), The Essential Dewey: Volume 1: Pragmatism, Education, Democracy (pp. 340-343). Bloomington, IN: Indiana University Press.

[7] Dewey, J., \& Tufts, J. H. (1908). Ethics. New York: Henry Holt and Company.

[8] Hildebrand, D. L. (2020). Rorty and Dewey. In: A. Malachowski (Ed.), The Wiley-Blackwell Companion to Rorty (pp. 335-356). Oxford: Wiley-Blackwell Press.

[9] James, W. (1987). Pragmatism: A new name for some old ways of thinking. In B. Kuklick (Ed.), William James, Writings, 1902-1910 (pp. 479-624). New York: Library of America.

[10] Koopman, C. (2006). Pragmatism as a philosophy of hope: Emerson, James, Dewey, Rorty. The Journal of Speculative Philosophy, 20(2), 106-116. https:/ / doi.org/10.1353/jsp.2006.0020

[11] Marshall, J. D. (1995). On what we may hope: Rorty on Dewey and Foucault. Studies in Philosophy and Education, 13(3-4), 307-323. https:/ / doi.org/10.1007/bf01077686

[12] Rondel, D. (2011). Anti-authoritarianism, meliorism, and cultural politics: On the Deweyan deposit in Rorty's pragmatism. Pragmatism Today 2(1), 56-67.

[13] Rorty, R. (1982a). Dewey's metaphysics. In: R. Rorty (Ed.), Consequences of Pragmatism (Essays: 1972-1980) (pp. 72-89). Minneapolis: University of Minnesota Press.

[14] Rorty, R. (1982b). Introduction: Pragmatism and philosophy. In: R. Rorty (Ed.), Consequences of Pragmatism (Essays: 1972-1980) (pp. xiii-xlvii). Minneapolis: University of Minnesota Press.

[15] Rorty, R. (1989). Contingency, Irony, and Solidarity. Cambridge, UK: Cambridge University Press.

[16] Rorty, R. (1991). The priority of democracy to philosophy. In: R. Rorty (Ed.), Objectivity, Relativism, and Truth: Philosophical Papers I. (pp. 175-196). Cambridge, UK: Cambridge University Press.

[17] Rorty, R. (1994). After philosophy, democracy. In: G. Borradori (Ed.), The American Philosopher: Conversations with Quine, Davidson, Putnam, Nozick, Danto, Rorty, Cavell, MacIntyre, and Kuhn (pp. 103-117). Chicago: University of Chicago Press.

[18] Rorty, R. (1995). Philosophy and the future. In: H. Saatkamp, Jr. (Ed.), Rorty and Pragmatism (pp. 197-205). Nashville, Tenn.: Vanderbilt University Press.

[19] Rorty, R. (1998a). A defense of minimalist liberalism. In: A. L. Allen \& M. C. Regan, Jr. (Eds.), Debating Democracy's Discontent: Essays on American Politics, Law, and Public Philosophy (pp. 117-125). New York: Oxford University Press.

[20] Rorty, R. (1998b). Dewey between Hegel and Darwin. In: R. Rorty (Ed.), Truth and Progress: Philosophical Papers III (pp. 290-306). Cambridge, UK: Cambridge University Press.

[21] Rorty, R. (1998c). Human rights, rationality and sentimentality. In: R. Rorty (Ed.), Truth and Progress: Philosophical Papers III (pp. 167-185). Cambridge, UK: Cambridge University Press.

[22] Rorty, R. (1998d). Rationality and cultural difference. In: R. Rorty (Ed.), Truth and Progress: Philosophical Papers III (pp. 186-201). Cambridge, UK: Cambridge University Press.

[23] Rorty, R. (1998e, April 23). The Next Left. Interview by Scott Stossel. Atlantic Unbound, https:/ / www.theatlantic.com/magazine/archive/1998/04/the-next-left/306010/

[24] Rorty, R. (1999a). Ethics without principles. In: R. Rorty (Ed.), Philosophy and Social Hope (pp. 72-92). New York: Penguin Books.

[25] Rorty, R. (1999b). Failed prophecies, glorious hopes. In: R. Rorty (Ed.), Philosophy and Social Hope (pp. 201-209). New York: Penguin Books.

[26] Rorty, R. (1999c). Achieving Our Country: Leftist Thought in Twentieth-Century America. Cambridge, Massachusetts: Harvard University Press.

[27] Rorty, R. (1999d). Afterword: Pragmatism, pluralism, and postmodernism. In: R. Rorty (Ed.), Philosophy and Social Hope (pp. 262-277). New York: Penguin Books.

[28] Rorty, R. (2007). Justice as a larger loyalty. In: R. Rorty (Ed.), Philosophy as Cultural Politics: Philosophical Papers IV (pp. 42-55). Cambridge, UK: Cambridge University Press.

[29] Rorty, R. (2010). An ethics for today. In: R. Rorty, G. Vattimo, G. Dann \& J. Robbins (Eds.), An Ethics for Today: Finding Common Ground Between Philosophy and Religion (pp. 7-26). New York: Columbia University Press.

[30] Shusterman, R. (1994). Pragmatism and liberalism between Dewey and Rorty. Political Theory, 22(3), 391-413. https:/ / doi.org/10.1177/0090591794022003002

[31] Voparil, Ch. J. (2014). Rorty and Dewey revisited: Toward a fruitful conversation. Transactions of the Charles S. Peirce Society, 50(3), 373-404. https:/ / doi.org/10.2979/trancharpeirsoc.50.3.373 